\title{
The Role of Good Corporate Governance to Fraud Prevention: An analysis based on the Fraud Pentagon
}

\author{
Binti Lailatur Rohmatin ${ }^{*}$, Gaguk Apriyanto2 ${ }^{2}$, Diana Zuhroh ${ }^{3}$ \\ ${ }^{1}$ Postgraduate University of Merdeka Malang, Indonesia \\ ${ }^{2}$ Secretary of the Master of Accounting Program, University of Merdeka Malang, Indonesia \\ ${ }^{3}$ Director of the Master of Accounting Program, University of Merdeka Malang, Indonesia \\ *Corresponding Author: lailaathori@gmail.com
}

\begin{abstract}
This study aims to analyze the relationship between the causes of fraud, good corporate governance, and fraud. This study is a descriptive study tested using logistic regression analysis. This study used 27 samples of banking companies from 44 banking companies during 2016-2019, so there were 108 observations. This analysis shows that competence and opportunity have a significant positive effect on fraud, but rationalization, pressure, and arrogance have no effect on fraud. This research also revealed that good corporate governance could minimize the influence of opportunity and rationalization on fraud, but good corporate governance strengthens the competence Impact on Fraud. Meanwhile, pressure and arrogance are not moderated by good corporate governance.
\end{abstract}

Keywords: Fraud; Pressure; Opportunity; Rationalization; Competence; Arrogance; Good Corporate Governance

\section{INTRODUCTION}

Fraud is known to cause materiality and non-materiality losses in organizations. According to the Association of Certified Fraud Examiners' (ACFE) 2016 Global Fraud Report, the average fraud loss in terms of asset misuse is US $\$ 125,000$. On average, corruption cases result in a loss of US $\$ 200,000$. The most negative effect was shown by false financial statements, which resulted in an average loss of up to US $\$ 975,000$. In 2019, ACFE commissioned a study in Indonesia and discovered that the finance and banking industries experienced the greatest losses due to fraud, accounting for up to $41.4 \%$ losses. Government fraud is ranked second, with a loss of $33.9 \%$. Fraud losses in other sectors were less than $6 \%$ of total revenue. The ACFE 2019 study reveals that fraud is mainly perpetrated by employees with $31.8 \%$, committed by administrators/owners up to $29.4 \%$, and managers up to $23.7 \%$, and others up to $15.2 \%$. Additionally, fraud was committed by $73.2 \%$ of perpetrators with an undergraduate qualification, $17.2 \%$ with a master's degree, $4.6 \%$ with a diploma level college degree, 4.2 percent with a high school diploma, and as many as 0.8 percent with a doctoral degree. 
In a company, the agent and principal partnership exists between management and shareholders (investors) bound by contracts. Management is responsible for meeting its expectations with the investors, whereas taxpayers are responsible for managerial returns (Jensen \& Meckling, 1976). The agent's and principal's differing goals, as well as the agent's misunderstanding of the appropriateness of the agent's actions, will lead to agency issues (Eisenhardt, 1989). Scott (2015) points out that some business transactions can have more detail than others, leading to information gaps (asymmetry information). The nature of these issues, as well as asymmetry information will provide an opening for those who seek to commit fraud.

Fraud is described as a deviant act or intentional omission to mislead, manipulate, or deceive consumers, banks, or other groups, resulting in losses; however, the fraudster makes a profit. (OJK, 2019). In addition, OJK, (2019) further explains that acts of fraud include deception, dishonesty, data leaking, asset mixing, bank crimes and all other fraud-related behavior. Fraud can come from internal parties (internal fraud) or from external parties (external fraud). Internal fraud is deception committed and perpetrated by management, including the board of commissioners, the board of directors, permanent staff, honorarium employees, and outsourcing employees (OJK, 2017).

In 1953, Donald R. Cressey first researched the fraud triangle hypothesis, such as coercion, perceived incentive, and rationalization, to why people have broken confidence and stole corporate cash. (Tuanakota, 2014). Pressure also comes from urgent needs, including the desire to live with neighbors or colleagues on an equal basis (Tuanakota, 2015). Chances are closely connected with the organization's culture or business and the failure of the internal management mechanism to deter, track and rectify the situation (Tuanakota, 2015). The perpetrator's justification for "pacifying himself" is referred to as rationalization. The perpetrator believes that everyone is corrupt, that everyone commits mistakes, or that he will return what he has stolen. (Tuanakota, 2015).

Wolfe \& Hermanson (2014) developed a fraud diamond by using competence as a factor in fraud. Competence is the capacity of an individual to perceive and experience the pressure, opportunity, and reason for engaging in fraud.Horwath (2011) proposed the concept of Pentagon fraud, claiming that it exists as a result of causes such as competence and arrogance.Horwath (2011)mentioned that competence refers to an employee's tendency to disregard internal controls, continue looking for opportunities to conceal lies, and exert power over social conditions for personal benefit. Arrogance is a fraudster with a large ego who believes he is a star, is autocratic in his leadership style, is fearful of losing his status, and enjoys intimidating others under the presumption that he will not be captured (Horwath, 2011).

The state of the financial stability of the company, the condition of personal or business finances, financial targets and external management pressure can cause pressure for management of the company. Profitability is one of the company's financial targets, which can put the company under pressure. Companies with a smaller profit margin have a proclivity to fabricate financial statements (Suyanto, 2009). Possibilities for fraud exist as a result of inadequate regulation, organizational structure, and the industry's culture. Ineffective monitoring has resulted in false financial statements (Aulia, Yendrawati, and Prabowo 2019). Suyanto (2009) demonstrates the opportunity of being the source of financial statement manipulation. Justification is a factor in false financial statements, which are very difficult to identify using published records, and are identified 
more accurately by interviews (Suyanto, 2009). However, Lastanti (2020) found that the rationalization reflected by auditors' change influenced false financial statements.

While pressure, opportunities, and rationalization may all motivate someone to act fraudulently, the perpetrator still requires competence to commit fraud (Wolfe \& Hermanson, 2004). Manurung \& Hardika (2015), Utami, Wijono, Noviyanti, \& Mohamed (2019) demonstrate that competence affects financial statements fraud. Moreover, someone who is selfish, portrays himself/herself as a celebrity, leads autocratically, is arrogant, and fears losing his status may be a driving force in fraud (Horward, 2011). According to Yusof's (2016) study, a CEO's photo can reflect arrogance. Yusof (2016) hypothesized that the report's extensive use of photographs of CEOs demonstrates that they are arrogant or that the report's extensive use of photographs of CEOs is intended to conceal their arrogance. The hypothesis was accepted in his dissertation, implying that arrogance has an impact on false financial statements.

Fraud will harm investors, particularly investors who are long-standing owners of corporate stock (Shi et al., 2017). Ozcelik, (2020) reports that fraudulent financial statements have resulted in financial scandals with accounting principles that negatively affect financial markets and cause investors to lose trust. Good corporate governance (GCG) is one of the public highlights of repeated irregularities and fraud cases (Sulistyanto, 2018). According to Financial Services Authority Regulation (POJK) Number 55 / POJK.03 / 2016 article 1 paragraph 7, Good corporate governance is the process of operating a bank in conformity with the five GCG principles of transparency, accountability, responsibility, independence, and fairness.

According to Shi et al. (2017) strict external supervision and monitoring will demotivate top management and diminish the value of internal focus, resulting in financial fraud. However, so much freedom can lead to decisions being taken by management that enrich themselves. Additionally, to mitigate the risk of false financial statements, companies raise the proportion of independent directors and boards of directors with accounting and financial knowledge, thus decreasing management-led boards' domination (Nasir et al., 2019).

The presence of a study gap demonstrates that there are still many discrepancies in the findings of previous studies, the majority of which were conducted in manufacturing companies. Particularly in assessing good corporate governance, which does not yet incorporate the five GCG principles. In this study, researchers selected the proxy for good corporate governance, e.g., GCG self-assessment, based on five principles of GCG composed of five ratings (rank 1, 2, 3, 4, \& 5). According to POJK Number 55 / POJK.03 / 2016, article 3, OJK evaluates the implementation of Bank governance. This assessment can be conducted by examining and reviewing the findings of bank's self-assessment (see article 68 paragraph (1). Based on the self-assessment results, OJK will request the bank to present an action plan containing required corrective measures with a certain target date (Article 68 paragraph (2). The action plan can also be amended or even submitted to a special review to determine the effectiveness of improved governance implementation (article 68, paragraph (3).

According to the report of ACFE (2016), there are several instances of fraud in the banking sector $(16.8 \%)$, and the financial and banking sectors suffered the largest fraud damages (41.4 \%). Employees perpetrated the majority of fraud (31.8 \%) (ACFE, 2019). This argument serves as a justification for researchers to pursue research in the financial 
industry and quantify fraud by internal fraud disclosures. This research investigates the impact of the fraud pentagon (pressure, opportunity, rationalization, capabilities, and arrogance) on fraud and investigates whether good corporate governance will help to mitigate fraud. This research contributes to an integrated empirical literacy between the factors of fraud, fraud, and good corporate governance.

\section{THE HYPOTHESIS DEVELOPMENT}

\section{Pressure and Fraud}

The burden of financial issues not shared due to concerns about social stigma will stimulate the development of motivations for crime (Dorminey et al., 2012). As described in Audit Standard 240, management or entities subjected to undue pressure from those responsible for corporate governance to reach financial targets, which may include revenue bonuses and third-party profitability, may raise the likelihood of potential fraud. Financial targets are goals which the company has defined and may constitute a different pressure for management to achieve company efficiency. The performance of the company can be observed from the profitability level. The percentage of return on assets (ROA) is one of the profitability metrics. Companies also use ROA to determine incentives, pay increases, and other benefits (Skousen et al., 2015). It increases management's motivation and drives to maximize the valuation of ROA. A high return on investment (ROI) implies a high profit margin, while a low ROA indicates a low-profit margin. So the management would be compelled to commit fraud. According to Harmono (2018), one of the profitability ratios that serves as a metric for opportunities is ROA, which indicates how efficiently a business uses its assets to generate income. According to Suyanto (2009), Skousen et al. (2015), Lastanti (2020), Utami et al. (2019), pressure is one of the reasons that contribute to the risk of financial statement fraud. However, a study by Ozcelik (2020) and Pamungkas et al. (2018) indicates that pressure has a detrimental impact on fraudulent financial statements. The first hypothesis that emerges from this explanation is:

$\mathrm{H}_{1}$ : Pressure has a positive impact on fraud.

\section{Opportunity and Fraud}

Opportunity emerges as a result of lax internal controls, and the belief of a risk of getting caught committing fraud will take a long time, Dorminey et al. (2012). Previous research relates to Suyanto (2009), in which opportunity is proxied by KAP BIG4 quality. The findings indicate that the efficiency of external auditors, as measured by KAP BIG4, has a strong and substantial impact on fraud. Ozcelik (2020) study study demonstrates that incentive, as measured by KAP quality, has a detrimental impact on fraudulent financial statements. The second hypothesis is constructed from this explanation as follows:

$\mathrm{H}_{2}$ : Opportunitiy has a positive impact on fraud

\section{Rationalization and Fraud}

Rationalization is the justification that allows the victim to feel comfortable with his behavior. Moreover, it has now evolved as the third factor that can lead to fraud. Rationalization allows for the reduction of correct or wrong thought and dissonance, allowing for the continuation of deception without remorse. Rationalization is the most challenging aspect to determine fraud risk factors, (Skousen et al., 2015). Rationalization is a risk factor that auditors of public data are very difficult to detect. Only by interviews, 
such as Cressey's in 1953, can rationalization be accurately articulated (Suyanto, 2009). However, Audit Standard 240 notes that the auditor must ensure that there are no substantial mistakes or frauds in the financial statements of the corporation that are audited. According to Audit Standard 240, one risk factor for rationalization is a strained and uncomfortable partnership between management and the successor or predecessor auditor. It can be in conflicts of opinion, unfair demands to auditors, improper limitation of auditor access, and influential management actions in communicating with auditors(IICPA (Indonesian Institute of Certified Public Accountants), 2014). It could be a sign of fraud and could prompt the corporation to change its external auditors. Research by Utami et al. (2019)andLastanti (2020) show that auditor reform is one source of financial report fraud.

$\mathrm{H}_{3}$ : Rationalization has a positive impact on fraud.

\section{Competence and Fraud}

Individuals who possess competence are constantly on the lookout for ways to commit fraud(Wolfe \& Hermanson, 2014). Horwath (2011) suggests that competence refers to an employee's tendency to disregard internal controls, continue looking for opportunities to conceal lies, and manipulate social situations for personal gain. It ensures that only someone with the competence to commit fraud will do so. Capabilities in some organizations, such as positions and functions, may provide openings for fraud that are not held by others (Wolfe \& Hermanson, 2014). The board of directors' reforms demonstrates the opportunity to transfer power from the former board of directors to the current board of directors to maximize the previous management's efficiency. It causes tension and paves the way for fraudulent activities during this process(Lastanti, 2020). Research from Manurung \& Hardika (2015), andUtami et al. (2019) use director transition as a proxy for competence and demonstrate a favorable impact on fraudulent financial statements. The following hypothesis is derived from this description:

$\mathrm{H}_{4}$ : Competence has a positive impact on fraud.

\section{Arrogance and Fraud}

Arrogance is a cheater with a large ego, who believes he is a star, who is autocratic in his leadership, who is fearful of losing his status, and who enjoys intimidating others by believing he will not be captured (Horwath, 2011). According to Yusof (2016) the presence of photographs of CEOs in annual reports indicates that the person is more brazen and that the risk of financial statement fraud is greater. The number of photographs in the annual report can also show CEOs' tendency to mask their greed and activity. Research by Apriliana \& Agustina (2017), Yusof (2016), indicates that the impact of arrogance on false financial statements is significant. The following hypothesis is derived from this explanation:

$\mathrm{H}_{5}$ : Arrogance positively impacts fraud

\section{Pressure, Opportunity, Rationalization, Competence, Arrogance, Good Corporate} Governance (GCG) and Fraud

According to Turnbull Report, effective corporate governance is the company's internal control system with the key goal of controlling major risks by protecting corporate assets and increasing long-term investor capital (Zarkasyi, 2018). The objectives of risk management include preventing, reducing, or even mitigating the negative impacts of market risks. To put it another way, strong corporate governance will mitigate 
market risk, ensuring that company assets are protected, and investment value rises. Fraud is one of the active threats that banks face since both internal and external actors can perpetuate it. Internal fraud is perpetrated by the bank's administrators, including the board of commissioners, directors, permanent employees, honorary employees, and contractors (Otoritas Jasa Keuangan, 2017b).

According to the study, fraud results from pressure, opportunity, rationalization, Competence, and arrogance. To succeed in enforcing effective corporate governance, the board of commissioners must establish an audit committee and other committees to independently monitor KAP processes and audits, Risk Assessment and Control processes, and Corporate Governance processes (Effendi, 2018). According to POJK Number 55/POJK.03/2016, banks are now expected to follow five GCG principles: transparency, accountability, responsibility, independence, and fairness. Banks are also expected to conduct self-assessments, which are then evaluated by the OJK and summarized in a report on GCG implementation. According to the findings of Nasir et al. (2019), the corporation reveals a growth in the improvement in good corporate governance after the company's encounter of fraud. So fraud-experiencing companies have become more aware of good governance, hoping that good governance can reduce fraud. According to Skousen et al. (2015) , the likelihood of fraud declines as the number of independent audit committee members (a key component of good corporate governance) increases. The following hypothesis is developed from this explanation:

$\mathrm{H}_{6}$ : GCG reduces the impact of pressure on fraud.

$\mathrm{H}_{7}$ : GCG reduces the impact of opportunity on fraud.

$\mathrm{H}_{8}$ : GCG reduces the impact of rationalization on fraud.

$\mathrm{H}_{9}$ : GCG reduces the impact of Competence on fraud.

$\mathrm{H}_{10}$ : GCG reduces the impact of arrogance on fraud.

\section{METHODS, DATA AND ANALYSIS}

This research employs a quantitative methodology in the form of explanatory analysis to demonstrate the importance of good corporate governance in minimizing fraud in Indonesia through the fraud pentagon. Secondary data was retrieved from the bank's official website or www.idx.com for the study. The sample population included all commercial banks listed on the Indonesia Stock Exchange between 2016 and 2019. Besides, purposive sampling was used to collect samples.

The conceptual framework for the study that will be used to test this hypothesis is as follows in Figure 1: 


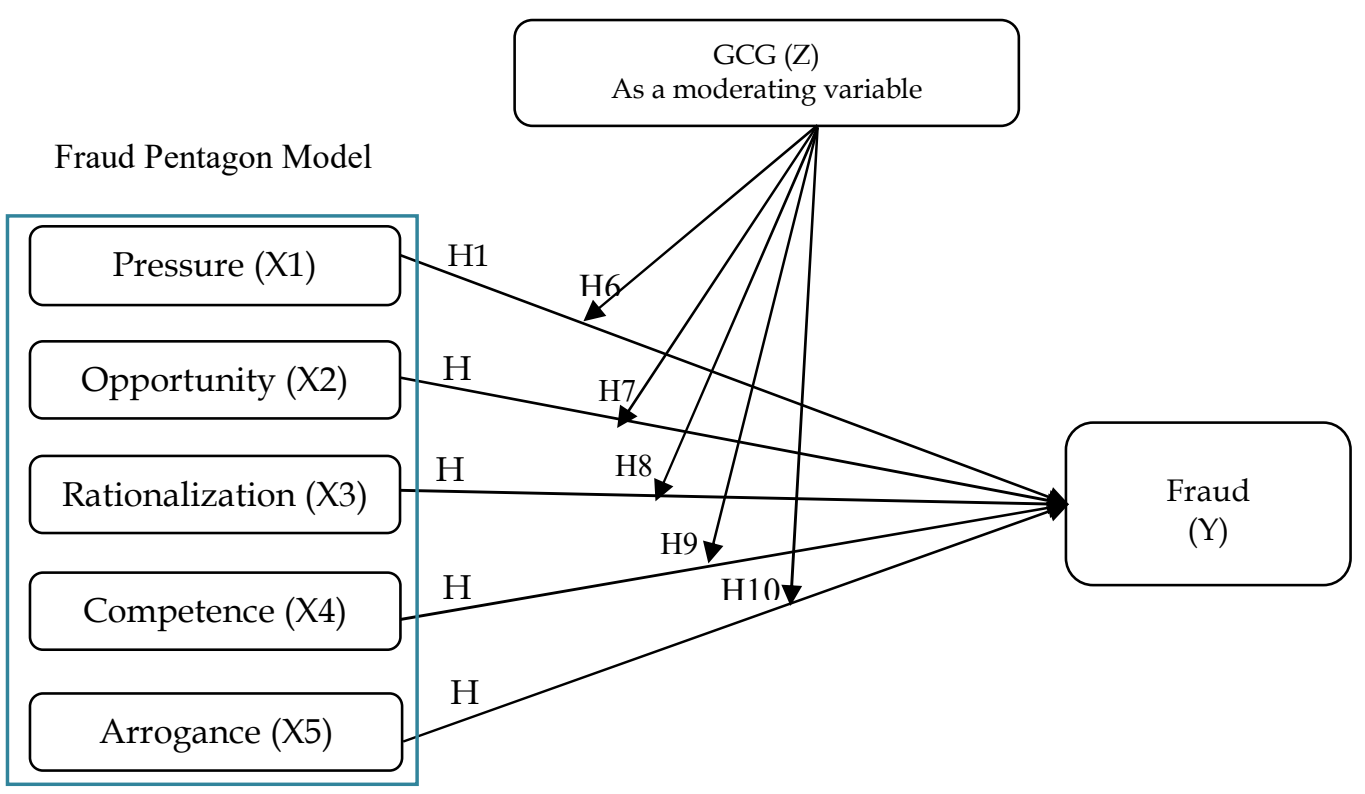

Figure 1. Conceptual framework for research

This study makes use of seven variables: one dependent variable, fraud, five independent variables, pressure, opportunity, rationalization, Competence, and arrogance, and one moderating variable, GCG. Table 1 contains the operational definitions for each variable.

Table 1. Variables operational definition

\begin{tabular}{|c|c|c|}
\hline $\begin{array}{l}\text { Variables \& } \\
\text { Notations }\end{array}$ & Measurement Indicator & Dimensions \\
\hline \multicolumn{3}{|c|}{ Dependent Variable } \\
\hline Fraud (Y) & $\begin{array}{l}\text { Dummy variable. If a Commercial Bank discloses an } \\
\text { internal fraud incident, the incident is coded } 1 \text {; } \\
\text { otherwise, the incident is coded } 0 .\end{array}$ & $\begin{array}{l}\text { Internal fraud } \\
\text { disclosure is } \\
\text { governed by the } \\
\text { OJK }\end{array}$ \\
\hline \multicolumn{3}{|c|}{ Independent Variables: Fraud Pentagon Model } \\
\hline Pressure (PRESS) & $\begin{array}{l}\text { The financial target is calculated by ROA } \\
=\text { after-tax profit } \\
\text { Assets in total }\end{array}$ & $\begin{array}{l}\text { Suyanto, (2009) } \\
\text { and Skousen et } \\
\text { al., (2015) }\end{array}$ \\
\hline $\begin{array}{l}\text { Opportunity } \\
\text { (OPP) }\end{array}$ & $\begin{array}{l}\text { KAP quality. Banks audited by KAP and associated to } \\
\text { BIG } 4 \text { receive code } 1 \text {, otherwise code } 0 .\end{array}$ & $\begin{array}{l}\text { Suyanto, (2009) } \\
\text { and Ozcelik, } \\
(2020)\end{array}$ \\
\hline $\begin{array}{l}\text { Rasionalization } \\
\text { (RAT) }\end{array}$ & $\begin{array}{l}\text { Change in the KAP. If there is a change in KAP during } \\
\text { the study, code } 1 \text { is assigned; if there is no change in } \\
\text { KAP, code } 0 \text { is assigned. }\end{array}$ & $\begin{array}{l}\text { Skousen et al., } \\
\text { (2015) and } \\
\text { Lastanti, (2020) }\end{array}$ \\
\hline $\begin{array}{l}\text { Competence } \\
(\mathrm{COMP})\end{array}$ & $\begin{array}{l}\text { Change in directors, If the board of directors is } \\
\text { changed, it will be coded } 1 \text {, if the board of directors is } \\
\text { not changed, it will be coded } 0 .\end{array}$ & $\begin{array}{l}\text { Manurung \& } \\
\text { Hardika (2015) }\end{array}$ \\
\hline Arrogance (ARR) & $\begin{array}{l}\text { Many such CEO photographs included in the annual } \\
\text { report }\end{array}$ & Yusof (2016) \\
\hline \multicolumn{3}{|c|}{ Moderating Variable } \\
\hline $\begin{array}{l}\text { Good Corporate } \\
\text { governance (GCG) }\end{array}$ & GCG self-assessment rating & OJK \\
\hline
\end{tabular}


The dependent variable in the present study is a non-metrical or categorical dummy variable. Then, data processing methods, in particular binary logistics, were used in logistic regression analysis. Meanwhile, logistic regression analysis does not require an assumption of normality from the independent variable data (Ghozali, 2011). Moderation of hypotheses testing is accomplished by the use of moderating regression analysis (MRA). The goodness of fit test is one of the requirements of logistic regression (Hosmer and lameshow test). The total model fit test will use $-2 \log$ likelihood or chi-square and model accuracy testing (omnibus test).

\section{Model 1:}

Y

$$
=\mathrm{a}+\beta_{1} \mathrm{PRES}+\beta_{2} \mathrm{OPP}+\beta_{3} \mathrm{RAT}+\beta_{4} \mathrm{COMP}+\beta_{5} \mathrm{ARR}+\mathrm{e}
$$

\section{Model 2:}

Y

$$
\begin{aligned}
& =\mathrm{a}+\beta_{1} \text { PRES }+\beta_{2} \mathrm{OPP}+\beta_{3} \text { RAT }+\beta_{4} \mathrm{COMP}+\beta_{5} \mathrm{ARR}+\beta_{6}\left(\mathrm{PRES}^{*} \mathrm{GCG}\right)+ \\
& \beta_{7}\left(\mathrm{OPP}^{*} \mathrm{GCG}\right)+\beta_{8}\left(\text { RAT }^{*} \mathrm{GCG}\right)+\beta_{9}\left(\mathrm{COMP}{ }^{*} \mathrm{GCG}\right)+\beta_{10}\left(\mathrm{ARR}^{*} \mathrm{GCG}\right)+\mathrm{e}
\end{aligned}
$$

\section{Description :}

$\begin{array}{ll}\text { Y } & =\text { Fraud } \\ \text { PRES } & =\text { Pressure } \\ \text { OPP } & =\text { Opportunity } \\ \text { RAT } & =\text { Rationalization } \\ \text { COMP } & =\text { Competence } \\ \text { ARR } & =\text { Arrogance } \\ \text { GCG } & =\text { Good Corporate Governance } \\ \text { a } & =\text { Constant } \\ \beta_{1} \text { s.d } \beta_{10} & =\text { Regression coefficient (slope) } \\ \mathrm{e} & =\text { Error }\end{array}$

\section{RESULT}

There are 44 registered banking firms. After being studied, it was discovered that a sample of 27 banks over the course of four years. As a result, the total number of observations is 108. Furthermore, Sampling criteria and results can be seen in table 2.

Table 2. Sampling criteria and results

\begin{tabular}{llc}
\hline No & \multicolumn{1}{c}{ Criteria } & 2016-2019 \\
\hline 1 & Banking companies on Indonesia Stock Exchange 2016-2019. & 44 \\
\hline 2 & $\begin{array}{l}\text { During the 2016-2019 cycle, the bank did not publish audited annual financial } \\
\text { reports online, either on its official website or on the IDX website. }\end{array}$ & $(0)$ \\
\hline 3 & During the period 2016-2019, research data has been reported incomplete. & $(9)$ \\
\hline 4 & $\begin{array}{l}\text { During the 2016-2019 study period, banks were excluded from the stock } \\
\text { market, and they were purchased, acquired, and consolidated. }\end{array}$ & $(8)$ \\
\hline 5 & About 2016 and 2019, the bank switched industries. & $(0)$ \\
\hline The number of companies used in the study's samples & 27 \\
\hline Number in samples of study (27 companies x 4 years) & 108 \\
\hline Source: processed data, 2021
\end{tabular}

\section{Descriptive Statistical Analysis}

The findings of predictive statistics show that there are 70 samples of fraud cases and 38 without fraud. Table 3 demonstrates that the fraud and non-fraud samples vary in gross assets and net income after tax. 
Table 3. Descriptive statistics

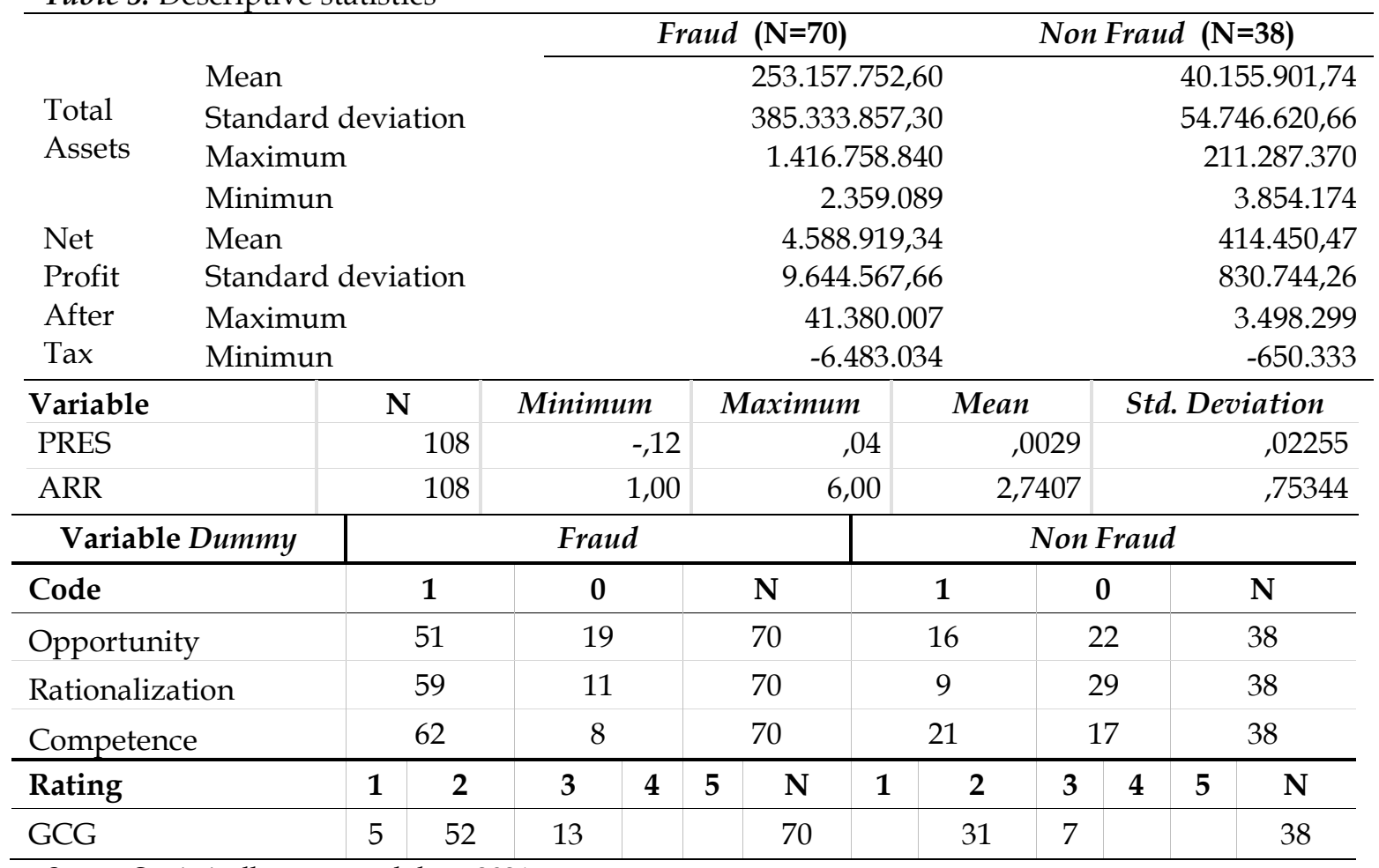

Source: Statistically processed data, 2021

\section{Logistic Regression Analysis}

The logistic regression findings in Table 4 indicate that the omnibus test model 1 is statistically meaningful at 0.000 less than $5 \%(<5 \%)$. It means that the model of regression is feasible. Additionally, the Hosmer and Lameshow tests are significant at a level greater than $5 \%(>5 \%)$, which indicates that the regression model fits the observed evidence. The measured chi-square value of model 1 is greater than the chi-square table value At the degree of freedom (df) 5,(24,920> 11,070). The inclusion of independent variables ensures that the regression model can be improved. Model 2 has a significant omnibus test value of 0,000 , the Hosmer and lameshow tests of 0,694 , and the chi-square measured is greater than the chi-square table at df $10(37,429>18,307)$. As a result, it can be inferred that models 1 and 2 satisfy the criteria for evaluating the hypothesis. The classification matrix indicates that the accuracy of prediction for regression models 1 and 2 is $75 \%$ and $78 \%$, respectively.

Table 4. Results of logistic regression analysis

\begin{tabular}{lrrr|r|rcrr}
\hline & \multicolumn{4}{c|}{ Model 1 } & \multicolumn{3}{c}{ Model 2 } \\
\hline Variable & B & Wald & Sig. & $\begin{array}{c}\text { Exp } \\
\text { (B) }\end{array}$ & B & Wald & Sig. & Exp (B) \\
\hline PRES &, 368 & $, 001,971$ & 1,445 & 24,261 & $, 158,691$ & 34388158660,000 \\
\hline OPP & 1,418 & $7,053,008^{*}$ & 4,130 & 11,006 & $9,440,002^{*}$ & 60209,982 \\
\hline RAT &, 160 & $, 061,805$ & 1,174 & 7,753 & $3,842,050^{* * *}$ & 2327,522 \\
\hline COMP & 1,858 & $11,964,001^{*}$ & 6,408 & $-7,380$ & $2,004,157$ &, 001 \\
\hline ARR &, 383 & $1,542,214$ & 1,467 & 1,652 & $1,027,311$ & 5,215 \\
\hline PRESGCG & & & & $-8,817$ & $, 168,682$ &, 000 \\
\hline OPPGCG & & & & $-4,316$ & $7,187,007^{*}$ &, 037 \\
\hline RATGCG & & & & $-3,294$ & $3,661,056^{* * *}$ &, \\
\hline
\end{tabular}




\begin{tabular}{|c|c|c|c|c|c|c|c|c|}
\hline & \multicolumn{3}{|c|}{ Model 1} & & & \multicolumn{3}{|c|}{ Model 2} \\
\hline Variable & $\bar{B}$ & Wald & Sig. & $\begin{array}{l}\text { Exp } \\
\text { (B) }\end{array}$ & $\bar{B}$ & Wald & Sig. & $\operatorname{Exp}(B)$ \\
\hline$\overline{\text { COMPGC }}$ & & & & & 4,502 & 3,068 &, $080^{\star \star *}$ & 90,221 \\
\hline ARRGCG & & & & &,- 590 & ,658 & 417 &, 554 \\
\hline Constant & $-2,665$ & 5,845 & ,016 & 070 & $-3,691$ & 7,445 & ,006 & ,025 \\
\hline \multicolumn{9}{|c|}{ N:108; * Signifikan pada 1\%, ** 5\%, dan *** 10\% } \\
\hline \multirow{2}{*}{\multicolumn{3}{|c|}{$\begin{array}{l}\text { Hosmer \& lameshow }(a>5 \%) \\
\text { Omnibus test }(a<5 \%)\end{array}$}} & & 0,208 & & & & 0,694 \\
\hline & & & & 0,000 & & & & 0,000 \\
\hline \multicolumn{3}{|l|}{ Chi square } & & 24.920 & & & & 37,429 \\
\hline \multicolumn{3}{|l|}{$d f$} & & 5 & & & & 10 \\
\hline \multicolumn{3}{|c|}{ Negelkerke R square } & & 0,284 & & & & 0,403 \\
\hline
\end{tabular}

\section{DISCUSSION}

The model 1 hypothesis test results indicate that $\mathrm{H} 1$ is rejected, indicating that pressure (PRES) has little impact on fraud (sig. 0971). The aim of calculating the profitability ratio in ROA is to evaluate the bank's performance. While financial targets evaluate performance, this is not one cause for fraud. It suggests that the bank's financial targets would raise bank employees' motivation to work professionally and improve their operational management at different levels. Motivation to work professionally and improvement of bank operating procedures should not make financial targets a burden. The results of this analysis affirm the studies conducted by Yendrawati et al. (2019) that enhanced profitability is not deemed as pressure if a company's operations are performed in a quality manner. Skousen et al. (2015) and Pamungkas et al. (2018) have concluded that the ROA-proxied pressure had no impact on fraud.

Hypothesis 2, The positive coefficient of opportunity (OPP) is 1.418 , with a significant value of 0.008 . (significant at $1 \%$ alpha), The means that opportunities have a positive impact on fraud. In this study, the BIG4 Public Accountant Firm (KAP BIG4) quality is used as a proxy of opportunity because it may show whether audit reports are of high or low quality. These high-quality audit findings would instill sufficient trust in financial analysts. This finding corresponds to Suyanto (2009) study, which indicates that audit quality, as measured by the audit company's size, brand, and capacity to mitigate agency issues, can influence fraud. KAP BIG4 usually performs high-quality audits such that fraud can be reduced (Suyanto, 2009).

The rationalization variable (RAT) has a significant value of 0.805 , indicating that $\mathrm{H} 3$ is rejected, which means no impact of rationalization on fraud. It illustrates why reforms to KAP do not lead to fraud. The change in KAP is decided by the Board of Commissioners and the audit committee during the audit engagement period, so the change in the KAP will not result in bank fraud. POJK No. 13 / POJK.03 / 2017 on the Use of Public Accountant Services and Public Accounting Firms in Financial Services Activities governs the hiring of KAP by banks, which are proposed by the board of commissioners based on the audit committee's recommendation and approved by the General Meeting of Shareholders (GMS), (Otoritas Jasa Keuangan, 2017a). It suggests that in the banking industry, changing KAP has its own set of rules and conditions. The results of this study support previous studies by Aulia et al. (2019), which found that management is used to working well with external auditors and, as a result, does not promote fraud even though they change. Suyanto (2009) research argues that external 
auditors struggle to identify risk factors for rationalization using publicly available data. Skousen et al. (2015) findings also show that direct interviews with the perpetrators better detect rationalization. Additionally, Pamungkas et al. (2018) and Suyanto (2009) state that rationalization, as proxied by the replacement of external auditors, has little impact on fraud.

Competence (COMP) is 0.001 with a positive coefficient of 1.858 at alpha $1 \%$. It indicates that $\mathrm{H} 4$ is accepted and that competence has a major beneficial impact on fraud. The shift of directors serves as a proxy for the competence variable. As contrasted with those without status and authority, status and authority are some of the competencies that can cause fraud. The findings of this analysis corroborate Wolf \& Hermanson's (2004) finding that competent individuals can identify and exploit openings for fraud. Additionally, this analysis confirms Horwath (2011) claim that competence exerts control over the social world, lacks internal controls, and results in deception for personal benefit. The findings of this analysis corroborate Lastanti (2020) research, which asserts that director changes create tension, which increases the likelihood of fraud. This result further reinforces Utami et al. (2019) which says that someone with competence is not afraid of risk and shows a strong will to engage in fraud. according to research by Manurung \& Hardika (2015) competence has a positive effect on fraud

In the statistical test for hypothesis 5, arrogance (ARR) has a significant value of 1.467. That is, arrogance does not affect fraud. The amount of images a person has does not always reflect their arrogance. Moreover, the photograph of the CEO was not prominent in the annual report of the bank. A photo with the board of directors and a photo for personal data profile purposes are often included in the annual report. Furthermore, a person's arrogance is a judgment of qualitative and subjective characteristics seen in their style, behavior, and attitude. Of course, different people have different levels of judgment when it comes to a person's arrogance. This study's rejection of H5 lends support to Lastanti (2020) research, which employs a proxy for the number of images of the CEO to detect arrogance and contend that It is preferable to build a new instrument for assessing arrogance rather than relying on the number of pictures of the CEO.

Additionally, Table 4 shows the results of regression model 2. which summarizes the MRA test results and concludes that $\mathrm{H} 7$ and $\mathrm{H} 8$ are accepted, with coefficient values of -4.316 and -3.294 , and a significant value of 0.007 (significant at the $1 \%$ level) and 0.056 (significant at the $10 \%$ level). GCG will mitigate only the opportunity and rationalization variables for their impact on fraud. The competence variable has a coefficient of 4.502 and a significance level of 0.080 . (significant at $10 \%$ level), the moderating factor GCG increases the impact of competence on fraud. As a result, H9 is rejected. The interaction coefficient for hypothesis $6(\mathrm{H} 6)$ is -8.817 , which is statistically significant at 0.682 . Hypothesis 10 (H10) interaction variable has a significant value of 0.417 with a coefficient of -0.590 , which suggests that H6 and H10 are rejected. Therefore GCG cannot moderate pressure and arrogance.

The important value of the pressure interaction vector with GCG (PRESGCG) is 0.682, which indicates that H6 has been rejected. GCG has little bearing on the impact of pressure on fraud. Financial targets act as a proxy for pressure, as calculated by ROA, which indicates how efficiently a bank's assets are used for profit. Financial targets are a constant in profit-oriented organizations. The idea is that corporate financial targets are 
not equal in the creation of pressure. As a result, while bank governance principles are derived from a single regulation, each organization's application and implementation differ. These results confirm Pamungkas et al. (2018)'s study, which showed that corporate governance mechanisms did not moderate the impact of financial fraud pressure.

Good corporate governance can mitigate significant risks and enhance investment value. Fraud is one of the operational risks of the bank that includes internal fraud and external fraud. The relationship between opportunities and GCG (OPPGCG) is significant, With a value of 0.007 and a negative coefficient of -4.316 , indicating that $\mathrm{H} 7$ is accepted. GCG is also capable of reducing the impact of opportunities on fraud. It ensures that good corporate governance reduces the likelihood of anyone committing fraud. The association between rationalization and GCG (RATGCG) is also accepted and confirms hypothesis 8 , which is that GCG mitigates the impact of rationalization on fraud. It suggests that the risk factors that rationalize fraud can be eliminated by introducing good corporate governance. Acceptance of hypotheses 7 and 8 is consistent with agency theory, which holds management accountable to clients for meeting their expectations, one of which is by the implementation of good corporate governance, which results in companies earning profits, fraud being reduced, and agency costs paid by investors in the form of management returns. In a previous study by Nasir et al. (2019), when a business experiences fraud, it will improve its corporate governance compared to when the company does not experience fraud.

Since the statistical findings of the association between competence and GCG (COMPGCG), H9 is rejected. The suggested hypothesis is that GCG reduces the impact of competence on fraud. However, the GCG findings reinforce the importance of competence in preventing fraud. Since a change of directors measures competence, this is conceivable. Managers are top management who can readily shift responsibilities, roles, and authorities as necessary. These reforms are almost unnoticeable when corporate governance is effective, and the reasons for the improvements are succinctly explained in the annual report, so the changes are not overly noticeable.

There is no significant relationship between arrogance and GCG, so H10 is rejected. Arrogance is a person's innate attitude. It is better if arrogant people control themselves first and then aspire to enforce good governance before being regulated in bank governance. As a result, when GCG fails to moderate the effect of arrogance on fraud, it is just normal. GCG, or good corporate governance, regulates specific elements applicable to bank operating procedures at all organizational levels. Thus enabling the adoption of good corporate governance based on the five GCG principles of Transparency, Accountability, Responsibility, Independence, and Fairness to be implemented collaboratively through the vision and mission of one organizational integrity. These results affirm the findings of Pamungkas et al. (2018), who discovered that corporate governance mechanisms do not moderate arrogance, and Lastanti (2020), who discovered that the audit committee, as part of good corporate governance, does not moderate the impact of arrogance on fraud. 


\section{CONCLUSIONS, LIMITATIONS, AND SUGGESTIONS}

\section{Conclusions}

This research discovered that fraud happens when someone has the opportunity to behave improperly. Furthermore, the competence factor often leads to fraud while the incidence of fraud is not determined by rationalization, pressure, and arrogance factors. Additionally, this study discovered that whilst enforcing effective corporate governance at all levels of the corporate organization will help minimize the occurrence of fraud triggered by opportunities and rationalization, the research also indicates that as corporate governance improves, one's competence to commit fraud increases. Another finding indicates that while banks properly enforce good corporate governance, the results were unable to moderate the pressure and arrogance factors which could lead to fraud.

\section{Limitations and Suggestions}

This study is restricted to a few proxies for each independent variable. As a result, it has a much lower probability of understanding the fraud pentagon independent variables (pressure, incentive, rationalization, competence, and arrogance) on fraud. To the future researchers, when selecting a theme that relates to this study, they can consider the research's limitations so that the research's shortcomings can be improved in further study.

This study is limited to opportunity proxies, including the quality of KAPBIG4, but this does not mean that organizations audited by KAP Non BIG4 are less qualified; each organization has its own rationale for engaging with KAP. In addition, the change in KAP serves as a proxy for the rationalization variable; however, not all KAP changes are due to fraud; rather, they are often required due to mutual decisions and OJK regulations. The change of directors serves as a proxy for the competence variable; however, not all changes of directors are triggered or led to fraud. Moreover, the number of photographs of the CEO in the annual report serves as a proxy for arrogance; however, not all of the photos on display demonstrate arrogance; rather, they are displayed for identification purposes.

\section{REFERENCES}

Abdulllahi, R., \& Mansor, N. (2015). Fraud Triangle Theory and Fraud Diamond Theory. Understanding the Covergent and Divergent For Future. 5(4), 38-45.

ACFE. (2016). Report To the Nations On Occupational Fraud and Abuse 2016. ACFE Report, 1-92.

ACFE. (2019). Survei Fraud Indonesia Chapter \#111. Auditor Essentials, 7-10.

Apriliana, S., \& Agustina, L. (2017). The Analysis of Fraudulent Financial Reporting Determinant through Fraud Pentagon Approach. Jurnal Dinamika Akuntansi, 9(2), 154-165. https:// doi.org/10.15294/jda.v7i1.4036

Dorminey, J., Scott Fleming, A., Kranacher, M. J., \& Riley, R. A. (2012). The evolution of fraud theory. Issues in Accounting Education, 27(2), 555-579. https:// doi.org/10.2308/iace-50131

Effendi, A. (2018). The Power of Good Corporate Governance Teori dan Implementasi (2nd ed.). 
Salemba Empat.

Eisenhardt, K. M. (1989). Agency Theory: An Assessment and Review. Cardiology, 14(1), 57-74. https://doi.org/10.1159/000169659

Ghozali, I. (2011). Aplikasi Analisis Multivariate Dengan Program IBM SPSS 19. Badan Penerbit-Undip.

Harmono. (2018). Manajemen Keuangan Berbasis Balanced Scorecard. Bumi Aksara.

Horwath, C. (2011). Why the Fraud Triangle is No Longer Enough. Www.Crowe.Com.

IICPA (Indonesian Institute of Certified Public Accountants). (2014). SA 240.pdf.

Jensen, M. C., \& Meckling, W. H. (1976). THEORY OF THE FIRM: MANAGERIAL BEHAVIOR, AGENCY COSTS AND OWNERSHIP STRUCTURE. Human Relations, 3, 305-360. https:/ / doi.org/10.1177/0018726718812602

Lastanti, H. S. (2020). Role of Audit Committee in the Fraud Pentagon and Financial Statement Fraud. International Journal of Contemporary Accounting, 2(1), 77. https:// doi.org/10.25105/ijca.v2i1.7163

Manurung, D. T. H., \& Hardika, A. L. (2015). Analysis of factors that influence financial statement fraud in the perspective fraud diamond: Empirical study on banking companies listed on the Indonesia Stock Exchange year 2012 to 2014. International Conference on Accounting Studies (ICAS), August. www.icas.my

Nasir, N. A. B. M., Ali, M. J., \& Ahmed, K. (2019). Corporate governance, board ethnicity and financial statement fraud: evidence from Malaysia. Accounting Research Journal, 32(3), 514-531. https:// doi.org/10.1108/ARJ-02-2018-0024

OJK. (2019). Salinan Peraturan Otoritas Jasa Keuangan Republik Indonesia Nomor 39 Pojk.03 2019. https://www.ojk.go.id/id/regulasi/Pages/Penerapan-Strategi-Anti-FraudBagi-Bank-Umum.aspx

Otoritas Jasa Keuangan. (2017a). Peraturan Otoritas Jasa Keuangan Nomor 13/POJK.03/ 2017 tentang Penggunaan Jasa Akuntan Publik dan Kantor Akuntan Publik Dalam Kegiatan Jasa Keuangan. Peraturan Otoritas Jasa Keuangan Nomor 13/POJK.03/2017 Tentang Penggunaan Jasa Akuntan Publik Dan Kantor Akuntan Publik Dalam Kegiatan Jasa Keuangan, 1-63.

Otoritas Jasa Keuangan. (2017b). Surat Edaran Otoritas Jasa Keuangan No 13/SEOJK.03/2017 tentang Penerapan Tata Kelola Bagi Bank Umum. Surat Edaran Otoritas Jasa Keuangan.

Ozcelik, H. (2020). An Analysis of Fraudulent Financial Reporting Using the Fraud Diamond Theory Perspective: An Empirical Study on the Manufacturing Sector Companies Listed on the Borsa Istanbul. 102, 131-153. https:// doi.org/10.1108/s1569-375920200000102012

Pamungkas, I. D., Ghozali, I., Achmad, T., Khaddafi, M., \& Hidayah, R. (2018). Corporate governance mechanisms in preventing accounting fraud: A study of fraud pentagon model. Journal of Applied Economic Sciences, 13(2), 549-560.

Scott, W. R. (2015). Financial Accounting Theory. Seventh Edition. Pearson Prentice Hall: Toronto. 
Shi, W., Connelly, B. L., \& Hoskisson, R. E. (2017). EXTERNAL CORPORATE GOVERNANCE AND FINANCIAL FRAUD: COGNITIVE EVALUATION THEORY INSIGHTS ON AGENCY THEORY PRESCRIPTIONS. Business, 38(April 2016), 1268-1286. https://doi.org/10.1002/smj

Skousen, C. J., Smith, K. R., \& Wright, C. J. (2015). Detecting and Predicting Financial Statement Fraud: The Effectiveness of The Fraud Triangle and SAS No. 99 in Corporate Governance and Firm Performance. In International Journal of Quality $\mathcal{E}$ Reliability Management (Vol. 13).

Sulistyanto, S. (2018). Manajemen Laba: Teori dan Model Empiris. PT Grasindo.

Suyanto, S. (2009). Fraudulent Financial Statement: Evidence from Statement on Auditing Standard No. 99. Gadjah Mada International Journal of Business, 11(1), 117. https:// doi.org/10.22146/gamaijb.5539

Tuanakota, T. M. (2014). Mendeteksi Manipulasi Laporan Keuangan. Salemba Empat.

Tuanakota, T. M. (2015). Audit Kontemporer. Salemba Empat.

Utami, I., Wijono, S., Noviyanti, S., \& Mohamed, N. (2019). Fraud diamond, Machiavellianism and fraud intention. International Journal of Ethics and Systems, 35(4), 531-544. https://doi.org/10.1108/IJOES-02-2019-0042

Wolfe, B. D. T., \& Hermanson, D. R. (2014). Print The Fraud Diamond : Considering the Four Elements of Fraud. 12(Exhibit 1), 1-5.

Yang, D., Jiao, H., \& Buckland, R. (2017). The determinants of financial fraud in Chinese firms: Does corporate governance as an institutional innovation matter? Technological Forecasting and Social Change, 125(August 2015), 309-320. https:// doi.org/10.1016/j.techfore.2017.06.035

Yendrawati, R., Aulia, H., \& Prabowo, H. Y. (2019). Detecting the Likelihood of Fraudulent Financial Reporting: an Analysis of Fraud Diamond. Asia-Pacific Management Accounting Journal, 14(1), 43-69.

Yusof, K. M. (2016). Fraudulent Financial Reporting: An Application of Fraud Models to Malaysian Public Listed Companies Being a Thesis submitted for the Degree of Doctor of Philosophy in the University of Hull by Khairusany Mohamed Yusof B . Acc (Honours ), Universiti Sain. August, 1-430.

Zarkasyi, W. (2018). Good Corporate Governance Pada Badan Usaha Manufaktur, Perbankan, dan Jasa Keuangan Lainnya. Alfabeta. 